\title{
Effect of Fatty Acid Modification on Prostacyclin Production by Cultured Human Endothelial Cells
}

\author{
Arthur A. Spector, John C. Hoak, Glenna L. Fry, Gerene M. Denning, \\ LyNN L. STOLL, and J. BRYAN SMITH, Departments of Biochemistry and Internal \\ Medicine, University of Iowa, Iowa City, Iowa 52242; Cardeza Foundation, \\ Thomas Jefferson University, Philadelphia, Pennsylvania 19107
}

\begin{abstract}
A B S T R A C T We have investigated whether changes in cellular fatty acid saturation can influence prostacyclin $\left(\mathrm{PGI}_{2}\right)$ production by cultured human umbilical vein endothelial cells. As compared to control cells, those enriched with linoleic acid released $60-75 \%$ less $\mathrm{PGI}_{2}$ in response to thrombin or the calcium ionophore A23187. A similar but considerably smaller effect was observed when the cells were enriched with oleic or linolenic acid, but no reduction occurred with palmitic or linoelaidic acids. Some reduction in $\mathrm{PGI}_{2}$ release was noted as early as $1 \mathrm{~h}$ after exposure to linoleic acid. When the culture medium was supplemented with linoleic acid, the cell phospholipids contained four to five times more linoleate and 25-40\% less arachidonate. These changes were most marked in the choline and serine plus inositol phosphoglyceride fractions. When the fatty acid composition of the cells enriched with linoleic acid was allowed to revert, there was a progressive increase in the capacity of the cells to release $\mathrm{PGI}_{2}$ in response to thrombin. The increase correlated with a reduction in linoleate content of the cell lipids, but there was no change in arachidonate content. This suggests that linoleic acid may act as an inhibitor of $\mathrm{PGI}_{2}$ production. The cultured endothelial cells were also able to produce $\mathrm{PGI}_{2}$ directly from added arachidonic acid. As the arachidonic acid concentration of the medium was raised, $\mathrm{PGI}_{2}$ formation by the linoleate-enriched cells increased relative to control cells, suggesting that the inhibition produced by linoleic acid may be competitive.
\end{abstract}

\section{INTRODUCTION}

Prostacyclin $\left(\mathrm{PGI}_{2}\right)^{1}$ is a prostaglandin that acts as a vasodilator and an inhibitor of platelet aggregation $(1,2) . \mathrm{PGI}_{2}$ is produced by a number of tissues, including

\footnotetext{
Address reprint requests to Dr. Spector, University of Iowa.

Received for publication 27 August 1979 and in revised form 7 January 1980.

${ }^{1}$ Abbreviations used in this paper: $\mathrm{PGI}_{2}$, prostacyclin; 6-keto- $\mathrm{PGF}_{1}$, the number 6-keto-derivative of prostaglandin $\mathrm{F}_{1}$.
}

blood vessel preparations (3-6). Endothelial cells in culture also synthesize $\mathrm{PGI}_{2}(7)$, and either arachidonic acid or prostaglandin endoperoxide $\mathrm{H}_{2}$ can serve as the substrate (8). $\mathrm{PGI}_{2}$ production by the endothelial cell is stimulated by thrombin, trypsin, or the calcium ionophore A23187 and is inhibited by acetylsalicylic acid (9-12). Because $\mathrm{PGI}_{2}$ probably is involved in the prevention of thrombosis, it is important to investigate the factors that regulate its production by the endothelium.

Human endothelial cells readily use free fatty acid, and much of the uptake is incorporated into cellular phosphoglycerides and acylglycerols (13). When endothelial cell monolayers are fed arachidonic acid, their inhibitory effect on platelet aggregation is enhanced (14), probably because $\mathrm{PGI}_{2}$ production is stimulated (8). An enhancement of the antiaggregating effect was not observed, however, when the cells were fed linoleic acid (14). This is unexpected, for linoleic acid serves as a precursor for arachidonic acid synthesis. Certain tumor cells cannot convert linoleate to arachidonate, but cultured human diploid cells are reported to contain this elongation and desaturation pathway $(15,16)$. In an attempt to investigate why linoleic acid did not potentiate the antiaggregating effect, we have measured $\mathrm{PGI}_{2}$ production by human umbilical vein endothelial cells that were enriched with linoleate in culture. Linoleic acid enrichment was associated with a decrease in the arachidonic acid content of the endothelial cell phospholipids and a considerable reduction in $\mathrm{PGI}_{2}$ release by the cells in response to thrombin or the calcium ionophore A23187. A similar but smaller effect occurred when the cells were enriched with oleic acid. These findings indicate that changes in fatty acid composition, particularly enrichment with linoleic acid, can affect the capacity of human endothelial cells to produce $\mathrm{PGI}_{2}$.

\section{METHODS}

Endothelial cell cultures. Endothelial cells were obtained from human umbilical veins (17), and primary cultures were 
prepared according to a slight modification of the method of Jaffe et al. (18). The cells were suspended in a modified medium 199 containing $20 \%$ fetal calf serum (17), seeded in $35 \times 10-\mathrm{mm}$ tissue culture dishes, and incubated in a $5 \%$ $\mathrm{CO}_{2}$ atmosphere at $37^{\circ} \mathrm{C}$. After $24 \mathrm{~h}$, this medium was replaced with $2 \mathrm{ml}$ of medium 199 containing $25 \mathrm{m.M}$ Hepes and $20 \%$ fetal calf serum. Two different experimental designs were used. In one, the cells were incubated for $72 \mathrm{~h}$ in either the medium without supplemental fatty acid or in the medium containing $0.15 \mathrm{mM}$ of added fatty acid. In the other, the cells were grown in the medium without added fatty acid for $72 \mathrm{~h}$, washed, and then exposed for $15-180 \mathrm{~min}$ to either the control or fatty acid supplemented medium. Cell counts were determined with a hemocytometer.

Preparation of fatty acid supplemented media. Fatty acids were obtained from NuChek Prep (Elysian, Minn.) and were $>99 \%$ pure as determined by gas licuid chromatography. The sodium salt was prepared and added dropwise while stirring to heat-inactivated fetal calf serum. Before addition of the fatty acid, the serum contained about $0.2 \mu \mathrm{mol} / \mathrm{ml}$ of free fatty acid, the concentrations of oleate, linoleate, and arachidonate being $0.049,0.012$, and $0.023 \mu \mathrm{mol} / \mathrm{ml}$, respectively. The free fatty acid concentration was determined colorimetrically (19). The serum was sterilized by filtration and then diluted so that the final free fatty acid concentration was $0.15 \mathrm{mM}$ and the molar ratio of total free fatty acid to bovine albumin contained in the $20 \%$ fetal calf serum was approximately three. There was no indication of endothelial cell damage as a result of culture for up to $6 \mathrm{~d}$ in the fatty acid supplemented media. The cells grew at the usual rate, reached the same density as in the control cultures, adhered well to the surface, and appeared to be normal by microscopic examination. Viability was determined by dye exclusion with erythrosin B. All cells excluded the dye regardless of the medium used.

$P G I_{2}$ assay conditions. A radioimmunoassay was employed to measure $\mathrm{PGI}_{2}$ production by the endothelial cells (12). The test medium was removed, and the monolayer of intact, confluent endothelial cells $\left(7-8 \times 10^{5}\right.$ cells, $0.2-0.3 \mathrm{mg}$ protein) in a $35 \times 10-\mathrm{mm}$ tissue culture dish was washed with incubation medium containing $0.125 \mathrm{mM}$ fatty acid-poor bovine serum albumin. After washing, $1 \mathrm{ml}$ of incubation medium alone or this medium containing thrombin or the calcium ionophore A23187 was added to the monolayer. The dish was incubated on a rocking platform at $37^{\circ} \mathrm{C}$ for $5 \mathrm{~min}$, and the supernatant solution was assayed for the stable metabolic product of $\mathrm{PGI}_{2}$, the number 6-keto-derivative of prostaglandin $\mathrm{F}_{1 \alpha}$ (6-keto-PGF $\left.{ }_{1 \alpha}\right)$, by a radioimmunoassay (12).

In another series of experiments, the ability of the cells to form $\mathrm{PGI}_{2}$ directly from arachidonic acid was assessed (8). After $1 \mathrm{ml}$ of the medium containing sodium arachidonate was added to the culture, the incubation was continued for $2-15 \mathrm{~min}$ at $37^{\circ} \mathrm{C}$. The supernatant solution was removed, centrifuged, and assayed for $\mathrm{PGI}_{2}$. In certain experiments, the medium contained $20 \mu \mathrm{M}$ sodium arachidonate, $140 \mathrm{mM}$ $\mathrm{NaCl}, 15 \mathrm{m.M}$ Tris- $\mathrm{HCl}$ and $5.5 \mathrm{m.M}$ glucose, $\mathrm{pH}$ 7.4. In others, the medium contained $10-400 \mu . \mathrm{M}$ sodium arachidonate, 50 $\mu . \mathrm{M}$ bovine serum albumin, $140 \mathrm{m.M} \mathrm{NaCl}, 5.8 \mathrm{mM} \mathrm{KCl}, 2.7$ $\mathrm{mM} \mathrm{CaCl}, 0.02-0.8 \mathrm{m.M} \quad \mathrm{Na}_{2} \mathrm{CO}_{3}$ and $16.3 \mathrm{mM}$ Tris$\mathrm{HCl}, \mathrm{pH} 7.4$

$\mathrm{PGI}_{2}$ radioimmunoassay. The radioimmunoassay was performed using an antiserum against 6-keto-PGF $\mathrm{PG}_{1 \alpha}(20)$. $100 \mu \mathrm{l}$ of either standard or samples was mixed with $100 \mu \mathrm{l}$ of $\left[{ }^{3} \mathrm{H}\right] 6$-keto- $\mathrm{PGF}_{1 \alpha}$ (New England Nuclear, Boston, Mass.) and $10 \mu \mathrm{l}$ antiserum at a dilution that bound $50 \%$ of the radioactivity in the absence of standard. After a $1-\mathrm{h}$ incubation at $37^{\circ} \mathrm{C}, 50 \mu \mathrm{l}$ IgGsorb (The Enzyme Center Inc., Tufts University School of Medicine, Boston, Mass.) was added, and the radioactivity contained in a $100-\mu$ l sample of the supernatant solution was measured in a liquid scintillation spectrometer. Assay detection limits were 0.3 pmol of 6-keto- $\mathrm{PGF}_{1 \alpha}$ and $50 \%$ inhibition was obtained with $3.3 \mathrm{pmol}$ of 6 -keto $\mathrm{PGF}_{1 \alpha}$. This assay has negligibly small amounts of cross reactivity with prostaglandins other than 6-keto$\mathrm{PGF}_{1 \alpha}$ (12).

Cell fatty acid analysis. Lipids were extracted from the endothelial cells with a $2: 1(\mathrm{vol} / \mathrm{vol})$ mixture of chloroform and methanol (21). Gas-liquid chromatography was used to analyze the fatty acid composition of the lipid extract (22). Phospholipids and neutral lipids were separated by thinlayer chromatography on silica gel G plates. The chromatograms were developed in a solvent system of hexane-diethyl ether-acetic:acid-methanol (170:40:4:4). After elution from the silica gel with chloroform-methanol $1: 1(\mathrm{vol} / \mathrm{vol})$, the phospholipid and neutral lipid fractions were saponified, and the fatty acids were extracted in hexane. After methylation (2:3), the fatty acid methyl esters were separated with a gas-licuid chromatograph containing a glass column of $2 \mathrm{~mm}$ inside diameter $\times 1.9 \mathrm{~mm}$, packed with $10 \%$ SP-2340 on $100 / 120$ mesh Chromosorb W-AW (Supelco, Inc., Bellefonte, Pa.).

Formation of radioactive prostaglandins. Endothelial cell monolayers were incubated for $5 \mathrm{~min}$ at $37^{\circ} \mathrm{C}$ with 2.5 $\mathrm{ml}$ of medium containing $8.75 \mathrm{nmol}$ of $\left[1-^{14}\right.$ C $]$ arachidonic acid (New England Nuclear, $55 \mathrm{Ci} / \mathrm{mol}$ ), $140 \mathrm{mM} \mathrm{NaCl}, 5.8$ $\mathrm{m.M} \mathrm{KCl}, 2.7 \mathrm{m.M} \mathrm{CaCl}$, $1.1 \mathrm{m.M} \mathrm{Na}_{2} \mathrm{CO}_{3}$, and $16.3 \mathrm{m.l}$ Tris $\mathrm{HCl}$ adjusted to $\mathrm{pH} 7.4$. Corresponding control incubations were done in empty dishes. After incubation, the medium was removed quantitatively, acidified to pH 3.5 with $1 . M$ citric acid, and extracted twice with 2 vol of ethyl acetate after addition of $\mathrm{NaCl}(24)$. Aliquots of the ethyl acetate extract were chromatographed with the organic phase of a mixture containing ethyl acetate:acetic acid:2,2,4-trimethyl pentane: $\mathrm{H}_{2} \mathrm{O}(110: 20: 50: 100)(8)$. After staining with $\mathrm{I}_{2}$ vapor and sublimation, the radioactivity contained in the outlined segments of silica gel was measured in a liquid scintillation spectrometer. In the empty dish controls, an average of only $0.45 \%$ of the added arachidonic acid radioactivity migrated in the region of the 6 -keto-PGF ${ }_{1 a}$ standard. This small amount of background radioactivity was subtracted from the quantity recovered in the 6-keto- $\mathrm{PGF}_{1 \alpha}$ region of the chromatograms from the incubations with endothelial cell monolayers.

\section{RESULTS}

Composition of endothelial cell lipids. When either oleic or linoleic acid was added to the culture medium, the fatty acid composition of the endothelial cell lipids was modified appreciably. This is illustrated by the data shown in Table I for cells incubated with these fatty acids for $72 \mathrm{~h}$. The control cells were cultured in media containing $20 \%$ fetal calf serum but no added fatty acid. The phospholipids of the control cells contained roughly equal amounts of saturated and polyenoic fatty acid and a slightly smaller amount of monoenoic fatty acid. Arachidonic acid (20:4) accounted for $15 \%$ of the phospholipid fatty acids, but the 18:2 and 20:3 contents were low. When the cells were grown in the presence of supplemental oleic acid,

${ }^{2}$ Fatty acids are abbreviated as chain length: number of double bonds. Thus, 20:4 represents a fatty acid containing 20 carbon atoms and four double bonds. 
TABLE I

Fatty Acid Composition of the Endothelial Cell Lipids after $72 \mathrm{~h}$ in Culture

\begin{tabular}{|c|c|c|c|c|c|c|}
\hline \multirow[b]{3}{*}{ Fatty acid } & \multicolumn{6}{|c|}{ Composition* } \\
\hline & \multicolumn{3}{|c|}{ Phospholipids } & \multicolumn{3}{|c|}{ Neutral lipids } \\
\hline & Controlt & Oleic & Linoleic & Control & Oleic & Linoleic \\
\hline & & & & & & \\
\hline \multicolumn{7}{|c|}{ Saturation classes } \\
\hline Saturated & 34.8 & 30.9 & 35.5 & 50.3 & 42.3 & 27.8 \\
\hline Monoenoic & 27.5 & 43.1 & 17.8 & 27.6 & 42.1 & 17.1 \\
\hline Polyenoic & 37.7 & 26.0 & 46.7 & 22.1 & 15.6 & 55.1 \\
\hline \multicolumn{7}{|c|}{ Individual acids $\S$} \\
\hline $16: 0$ & $11.5 \pm 2.2$ & $13.1 \pm 2.1$ & $14.6 \pm 2.2$ & $18.4 \pm 3.1$ & $17.4 \pm 3.2$ & $13.4 \pm 2.4$ \\
\hline $16: 1$ & $2.2 \pm 0.8$ & $1.6 \pm 0.2$ & $1.6 \pm 0.3$ & $2.5 \pm 0.3$ & $3.1 \pm 0.6$ & $1.8 \pm 0.4$ \\
\hline 18:0 & $20.6 \pm 1.4$ & $16.4 \pm 0.6$ & $18.7 \pm 1.0$ & $27.5 \pm 1.3$ & $20.0 \pm 5.6$ & $10.9 \pm 0.9$ \\
\hline $18: 1$ & $22.7 \pm 0.9$ & $39.7 \pm 1.5$ & $14.1 \pm 1.0$ & $23.0 \pm 2.8$ & $34.3 \pm 5.0$ & $10.9 \pm 0.3$ \\
\hline $18: 2$ & $5.1 \pm 1.0$ & $3.5 \pm 0.6$ & $24.2 \pm 1.0$ & $7.2 \pm 2.2$ & $2.9 \pm 0.5$ & $30.7 \pm 1.4$ \\
\hline $20: 2$ & ND" & ND & $4.3 \pm 0.1$ & ND & ND & $4.5 \pm 0.3$ \\
\hline $20: 3$ & $2.6 \pm 0.2$ & $1.5 \pm 0.1$ & $1.5 \pm 0.1$ & $2.4 \pm 0.5$ & $1.9 \pm 0.1$ & $3.0 \pm 0.3$ \\
\hline $20: 4$ & $15.1 \pm 1.4$ & $11.0 \pm 1.0$ & $8.9 \pm 0.4$ & $4.5 \pm 3.5$ & $2.4 \pm 0.4$ & $3.8 \pm 0.3$ \\
\hline $20: 5$ & $0.9 \pm 0.1$ & $0.5 \pm 0.3$ & ND & ND & ND & $0.8 \pm 0.6$ \\
\hline $24: 1$ & $4.7 \pm 0.5$ & $3.7 \pm 0.4$ & $3.5 \pm 0.1$ & $1.4 \pm 0.5$ & $3.5 \pm 0.9$ & $4.8 \pm 0.1$ \\
\hline $22: 5$ & $4.1 \pm 0.4$ & $2.8 \pm 0.4$ & $2.3 \pm 0.3$ & $1.8 \pm 0.7$ & $2.6 \pm 0.9$ & $4.0 \pm 0.4$ \\
\hline $22: 6$ & $4.2 \pm 0.5$ & $2.5 \pm 0.8$ & $2.4 \pm 0.1$ & $1.3 \pm 0.5$ & $0.9 \pm 0.5$ & $2.2 \pm 0.3$ \\
\hline
\end{tabular}

* Values are the mean $\pm \mathrm{SE}$ of four separate cultures.

$\$$ Medium in which the cells were cultured for $72 \mathrm{~h}$ : control, no added fatty acid; $150 \mu \mathrm{M}$ oleic or linoleic acid added as a supplement.

$\$$ Only the major individual acids are listed, and these percentages do not total to $100 \%$.

"ND, $<0.5 \%$.

the monoenoic fatty acid content of the phospholipids increased by almost $60 \%$ and the polyenoic fatty acid content decreased by about $45 \%$. These changes resulted primarily from a large increase in the percentage of 18:1 and decreases in all of the polyenoic fatty acids, including 18:2 and 20:4. Supplementation of the medium with linoleic acid produced opposite changes in the phospholipid fatty acid composition. Under these conditions, the monoenoic fatty acid content was reduced by $\sim 40 \%$ and the polyenoic fatty acid content increased by $\sim 25 \%$ relative to the control cells. This was accounted for primarily by a large decrease in the percentage of $18: 1$ and an almost fivefold increase in 18:2. In spite of this large increase in $18: 2$, there was a reduction in the $20: 3$ and $20: 4$ contents, the latter being $40 \%$ lower than in the control cells. There was little change in the saturated fatty acid content of the phospholipids when the cells were grown in the media containing supplemental unsaturated fatty acids.

Similar but even more marked changes were noted in the neutral lipid fraction of the endothelial cells when they were cultured in the presence of supplemental oleic or linoleic acid. Unlike in the phospho- lipids, however, appreciable reductions in the percentage of saturated fatty acid in the neutral lipids occurred in both fatty acid supplemented cell preparations, the decrease being greater in the cells grown in the presence of linoleic acid. There was no change in the percentage of $20: 4$ in the neutral lipids of the linoleic acid supplemented cells even though the percentage of 18:2 in this fraction increased $>$ fourfold.

The fatty acid compositions of three main phosphoglyceride fractions isolated from the endothelial cell phospholipids are shown in Table II. The composition of each of these phosphoglycerides was altered when the cells were grown in the fatty acid supplemented medium, but the changes in 18:2 and 20:4 were smaller in phosphatidylethanolamine than in the other two fractions. In phosphatidylcholine, there was a considerable increase in 18:1 in the oleate supplemented and a very large increase in 18:2 in the linoleate supplemented cells. In both cases, there was a decrease in the 20:4 content, the reduction being greater in the linoleate supplemented cells. Similar fatty acid compositional changes occurred in the phosphatidylserine plus phosphatidylinositol fraction.

Fatty acid composition data also were obtained when 
TABLE II

Fatty Acid Composition of Phosphoglycerides from Cultured Human Endothelial Cells

\begin{tabular}{|c|c|c|c|c|c|c|c|c|c|}
\hline \multirow{3}{*}{$\begin{array}{c}\text { Fatty } \\
\text { acid }\end{array}$} & \multicolumn{9}{|c|}{ Composition* ${ }^{*}$} \\
\hline & \multicolumn{3}{|c|}{ Phosphatidylcholine } & \multicolumn{3}{|c|}{ Phosphatidylethanolamine } & \multicolumn{3}{|c|}{$\begin{array}{l}\text { Phosphatidylserine plus } \\
\text { phosphatidylinositol }\end{array}$} \\
\hline & Control & Oleic & Linoleic & Control & Oleic & Linoleic & Control & Oleic & Linoleic \\
\hline & \multicolumn{9}{|c|}{$\%$} \\
\hline $16: 0$ & 31.0 & 17.0 & 22.7 & 3.0 & 7.4 & 8.0 & 4.4 & 7.4 & 11.5 \\
\hline $16: 1$ & 3.6 & 2.4 & 2.7 & ND & 1.5 & 1.3 & ND & 0.6 & ND \\
\hline $18: 0$ & 17.5 & 9.2 & 14.5 & 21.5 & 15.7 & 17.7 & 32.3 & 27.0 & 29.1 \\
\hline $18: 1$ & 30.7 & 53.1 & 14.3 & 18.1 & 21.5 & 12.0 & 24.5 & 40.1 & 18.4 \\
\hline $18: 2$ & 4.5 & 3.9 & 32.3 & 3.3 & 2.8 & 6.5 & 4.5 & 4.0 & 18.1 \\
\hline $20: 2$ & ND $\ddagger$ & ND & 3.0 & ND & ND & 2.7 & ND & 1.8 & ND \\
\hline $20: 3$ & 1.0 & 0.8 & 0.7 & 1.4 & ND & 0.8 & 3.1 & 2.1 & 1.1 \\
\hline $20: 4$ & 10.6 & 8.5 & 5.9 & 23.1 & 18.6 & 20.2 & 13.3 & 5.4 & 5.5 \\
\hline $20: 5$ & ND & ND & ND & 1.1 & ND & 0.4 & 0.4 & ND & ND \\
\hline $22: 5$ & 0.4 & 1.5 & 0.4 & 7.1 & 14.2 & 6.8 & 4.6 & 2.9 & 3.7 \\
\hline $22: 6$ & ND & 0.7 & ND & 10.4 & 12.6 & 9.8 & 4.7 & 3.5 & 3.8 \\
\hline
\end{tabular}

* Values are the average of two determinations. The experimental design was the same as that described in Table I. $\ddagger \mathrm{ND},<0.5 \%$.

the endothelial cells were cultured in the media supplemented with fatty acid for short periods of time. The phospholipid fatty acid composition results are listed in Table III. Cells grown in a medium containing supplemental oleic acid exhibited very little change in phospholipid fatty acid composition after either 1 or $3 \mathrm{~h}$ of culture. By contrast, the 18:2 content of the cell phospholipids increased by $60 \%$ after $1 \mathrm{~h}$ and by $110 \%$ after $3 \mathrm{~h}$ when the medium was supplemented with linoleic acid. The $20: 4$ content of the phospholipids decreased by only 8 and $13 \%$ at 1 and $3 \mathrm{~h}$, however, in the linoleic acid supplemented medium. Therefore, after relatively short periods of exposure to supplemental linoleic acid, the relative increase in the 18:2 content of the cell phospholipids was appreciable whereas the decrease in 20:4 content was minimal.

$\mathrm{PGI}_{2}$ release. The endothelial cells enriched with linoleic or oleic acid released less $\mathrm{PGI}_{2}$ in response

TABLE III

Composition of Cell Phospholipids after Short Exposures to Media Containing Supplemental Fatty Acids*

\begin{tabular}{|c|c|c|c|c|c|c|}
\hline \multirow{3}{*}{$\begin{array}{l}\text { Fatty } \\
\text { acid }\end{array}$} & \multicolumn{6}{|c|}{ Phospholipid composition $t$} \\
\hline & \multicolumn{3}{|c|}{$1 \mathrm{~h}$} & \multicolumn{3}{|c|}{$3 \mathrm{~h}$} \\
\hline & Control & Oleic & Linoleic & Control & Oleic & Linoleic \\
\hline & \multicolumn{6}{|c|}{$\%$} \\
\hline 16:0 & 14.2 & 14.5 & 13.7 & 16.1 & 11.5 & 13.3 \\
\hline 18:0 & 20.2 & 20.3 & 19.7 & 20.0 & 18.2 & 16.7 \\
\hline 18:1 & 26.5 & 27.8 & 26.4 & 25.1 & 27.6 & 21.0 \\
\hline $18: 2$ & 4.0 & 3.8 & 6.5 & 3.8 & 3.9 & 8.0 \\
\hline $20: 4$ & 12.8 & 12.2 & 11.8 & 12.5 & 14.2 & 10.9 \\
\hline $22: 5$ & 3.9 & 3.8 & 3.7 & 4.3 & 3.4 & 3.5 \\
\hline $22: 6$ & 4.5 & 4.4 & 4.1 & 4.0 & 3.7 & 3.3 \\
\hline
\end{tabular}

* The experimental design was the same as that described in Table I except that the cells were exposed to the media supplemented with either oleic or linoleic acid for only 1 or $3 \mathrm{~h}$ at the end of the 72 -h culture period. Each value is the average of two determinations.

\$ Only the major fatty acids are included and, therefore, the values do not add up to $100 \%$. 
to $0.5 \mathrm{U}$ thrombin, as compared to the cells grown in the control medium. Control cells released $165 \pm 10$ pmol of $\mathrm{PGI}_{2}(n=10)$. Those enriched with oleic acid for $72 \mathrm{~h}$ released $110 \pm 9$ pmol, a $30 \%$ decrease. The cells enriched with linoleic acid for $72 \mathrm{~h}$ released $50 \pm 5$ pmol, a $70 \%$ decrease as compared to the control cells.

$\mathrm{PGI}_{2}$ production from added arachidonate. The work of Marcus et al. (8) indicated that endothelial cells produce $\mathrm{PGI}_{2}$ when arachidonic acid is added to the assay medium, without the need for a stimulating agent such as thrombin (8). This procedure was employed to determine whether fatty acid enrichment also would influence the ability of the cells to produce $\mathrm{PGI}_{2}$ when arachidonic acid was available in the assay medium. In the initial experiments with control cells, we compared $\mathrm{PGI}_{2}$ production measured by the radioimmunoassay to that measured in duplicate incubations containing $\left[1-{ }^{14} \mathrm{C}\right]$ arachidonic acid by thin-layer chromatography (8). It was assumed in calculating the thin-layer chromatography results that there was no dilution of the added $\left[1-{ }^{14} \mathrm{C}\right]$ arachidonic acid by endogenous unlabeled substrate. The $\mathrm{PGI}_{2}$ production as measured by the radioimmunoassay was $408 \pm 46$ $\mathrm{pmol} / \mathrm{ml}$, whereas the value obtained by thin-layer chromatography was $572 \pm 76 \mathrm{pmol} / \mathrm{ml}(n=5)$. These results are interpreted to indicate that essentially all of the $\mathrm{PGI}_{2}$ produced in this assay is derived directly from the arachidonic acid added to the medium.

With the radioimmunoassay procedure, we tested the ability of the cells enriched with fatty acid to produce $\mathrm{PGI}_{2}$ when the medium contained $20 \mu \mathrm{M}$ arachidonic acid but no albumin. Release was considerably greater under these conditions than when the thrombin stimulus was employed. No significant differences in $\mathrm{PGI}_{2}$ release were observed, however, when the control cells were compared to those grown in the media supplemented with either oleic or linoleic acid.

Additional experiments were done to determine whether the availability of extracellular arachidonic acid would influence the capacity of the cells enriched with linoleic acid to produce $\mathrm{PGI}_{2}$. Each of the assay media contained $50 \mu \mathrm{M}$ albumin and, as shown in Table IV, the arachidonic acid concentration was varied from 10 to $400 \mu . \mathrm{M}$. As the arachidonic acid concentration was raised, the amount of $\mathrm{PGI}_{2}$ produced by both types of cells increased markedly. Moreover, relative to the control cells, progressively more $\mathrm{PGI}_{2}$ was produced by the cells enriched with linoleic acid as the arachidonic acid concentration was raised. For example, the cells enriched with linoleic acid released only $16 \%$ as much $\mathrm{PGI}_{2}$ as the control cells when $10 \mu \mathrm{M}$ arachidonic acid was present, whereas they released $92 \%$ as much when the arachidonic acid concentration was $400 \mu \mathrm{M}$. At the higher arachidonic acid concentrations, and the cells enriched with linoleic
TABLE IV

Effect of Arachidonic Acid Concentration on Prostacyclin Production*

\begin{tabular}{|c|c|c|c|}
\hline \multirow{2}{*}{$\begin{array}{l}\text { Arachidonic } \\
\text { acid }\end{array}$} & \multicolumn{2}{|c|}{$\mathrm{PGI}_{2}$ production } & \multirow{2}{*}{$\begin{array}{c}\text { Ratio } \\
\text { (linoleic/ } \\
\text { control) })\end{array}$} \\
\hline & Linoleic & Control & \\
\hline$\mu \mathrm{M}$ & \multicolumn{2}{|c|}{ pmol } & \\
\hline 10 & 4 & 25 & 0.16 \\
\hline 50 & 46 & 77 & 0.46 \\
\hline 100 & 63 & 97 & 0.65 \\
\hline 400 & 707 & 883 & 0.92 \\
\hline
\end{tabular}

* Cultured endothelial cells grown in either the control medium or one supplemented with $150 \mu \mathrm{M}$ linoleic acid were washed and then assayed for $\mathrm{PGI}_{2}$ production in a medium containing arachidonic acid. The assay medium also contained $50 \mu \mathrm{M}$ albumin, and the time of incubation was $5 \mathrm{~min}$. The content of 6-keto-PGF ${ }_{1 \alpha}$ in the medium was measured by radioimmunoassay. Each value is the average of three separate cultures.

$\$ \mathrm{PGI}_{2}$ produced by the cells enriched with linoleic acid divided by the $\mathrm{PGI}_{2}$ produced by the cells grown in unsupplemented medium.

acid produced almost as much $\mathrm{PGI}_{2}$ as the control cells, a finding consistent with what is observed when no albumin is present and the unbound arachidonic acid concentration is high.

Effect of thrombin concentration and time. As seen in Fig. 1, the differences in $\mathrm{PGI}_{2}$ release in response to thrombin between the control and fatty acid-enriched cells were observed at all thrombin concentrations between 0.05 and $1.0 \mathrm{U} / \mathrm{ml}$. At each concentration,

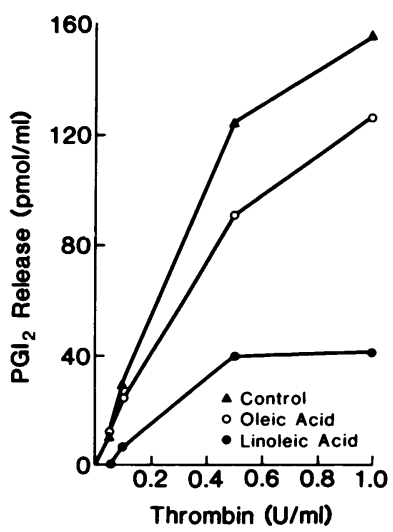

FIGURE 1 Effect of thrombin concentration on $\mathrm{PGI}_{2}$ release by the cultured endothelial cells. Cells were cultured for $72 \mathrm{~h}$ in one of three media before assay for $\mathrm{PGI}_{2}$ production: control, no added fatty acid; oleic, $150 \mu . \mathrm{M}$ oleic acid added as free fatty acid; linoleic, $150 \mu .11$ linoleic acid added as free fatty acid. These media were removed and the cells washed with a 125- $\mu . \mathrm{M}$ albumin solution before exposure to thrombin. Each point is the average obtained from two to four separate endothelial cell preparations. 
considerably greater reductions occurred with the linoleate than with the oleate-enriched cells. In additional experiments, we found that the differences between the control and fatty acid-enriched cells persisted at thrombin concentrations up to $5.0 \mathrm{U} / \mathrm{ml}$.

The lesser $\mathrm{PGI}_{2}$ production by the fatty acid-enriched cells could not be overcome by repeated exposures to thrombin. Essentially, all of the $\mathrm{PGI}_{2}$ release occurred during the first exposure to $0.5 \mathrm{U} / \mathrm{ml}$ of thrombin in both the control and fatty acid-enriched cells. The release by the linoleate-enriched cells was almost $70 \%$ less after the first exposure to thrombin and also $\sim 70 \%$ less cumulatively after the fourth exposure. A similar result was obtained with the oleate-enriched cells, but the reduction in $\mathrm{PGI}_{2}$ release was only $40 \%$ less as compared to the control cells.

There was an effect on $\mathrm{PGI}_{2}$ production in response to thrombin as early as $\mathrm{l} \mathrm{h}$ after the cells were exposed to the medium containing supplemental linoleic acid. As compared to the control cells, the cells incubated with linoleic acid for the $1 \mathrm{~h}$ released $40 \%$ less $\mathrm{PGI}_{2}$. By contrast, the effects of short-term exposure to oleic acid were quite variable, and no consistent difference as compared to the control cells was noted during the first $24 \mathrm{~h}$.

Other fatty acids. In an attempt to determine whether the reductions in thrombin stimulated $\mathrm{PGI}_{2}$ release might be a nonspecific toxic effect, additional fatty acids were tested. As shown in Table V, supplementation of the culture medium with linoleic acid produced a $76 \%$ reduction in $\mathrm{PGI}_{2}$ release in this series of experiments. By contrast, linoelaidic acid, the trans, trans-isomer of linoleic acid, produced only a $7 \%$ reduction. There was no reduction when the medium was supplemented with palmitic acid, a saturated fatty acid. Linolenic acid, a trienoic polyunsaturate of the

TABLE V

Effect of Supplemental Fatty Acids on Cell Growth and Prostacyclin Release*

\begin{tabular}{lcc}
\hline \multicolumn{1}{c}{ Supplement } & PGI $_{2}$ release & Cell count \\
\hline & $p m o l$ & $\times 10^{-6}$ \\
None & $138 \pm 7$ & $1.05 \pm 0.05$ \\
Linoleic $(18: 2 n-6)$ & $33 \pm 2 \ddagger$ & $0.94 \pm 0.06$ \\
Linoelaidic $(18: 2 n-6 \mathrm{t}, \mathrm{t})$ & $129 \pm 6$ & $0.88 \pm 0.07$ \\
Palmitic $(16: 0)$ & $144 \pm 8$ & $1.03 \pm 0.04$ \\
Linolenic $(18: 3 n-3)$ & $90 \pm 9 \S$ & $0.94 \pm 0.03$ \\
\hline
\end{tabular}

* The procedure was the same as that described for the thrombin stimulated release in Fig. 1. The culture media were supplemented with $150 \mu \mathrm{M}$ of the fatty acid, and $0.5 \mathrm{U}$ of thrombin was added to elicit $\mathrm{PGI}_{2}$ release. Each value is the mean $\pm \mathrm{SE}$ of six separate cultures.

$\ddagger P<0.001$.

$\S P<0.01$. $n-3$ series, produced only a $35 \%$ reduction. Therefore, of the fatty acids tested, only linoleic acid consistently produced a decrease in $\mathrm{PGI}_{2}$ release of $50 \%$ or greater in response to thrombin. The cell counts were not appreciably reduced when supplemental fatty acids were present in the culture medium. Linoelaidic acid, which produced the largest decrease in cell count ( $16 \%$ ), had essentially no effect on $\mathrm{PGI}_{2}$ release. Taken together, these findings indicate that a nonspecific toxic action is not the mechanism whereby supplemental linoleic acid inhibits the thrombin stimulated release of $\mathrm{PGI}_{2}$.

$\mathrm{PGI}_{2}$ release in response to a calcium ionophore. In addition to thrombin, the calcium ionophore A23187 stimulated $\mathrm{PGI}_{2}$ production, and differences in $\mathrm{PGI}_{2}$ release between the control cells and those grown in the fatty acid supplemented media were observed. The effects of exposure to the fatty acid supplemented media for $15 \mathrm{~min}$ to $72 \mathrm{~h}$ are shown in Table VI. The largest difference between the control and oleic acid supplemented cells at any of the times tested was $\sim 10 \%$. There was a $13-27 \%$ decrease in $\mathrm{PGI}_{2}$ release from cells exposed to linoleic acid during the first $3 \mathrm{~h}$ and after $72 \mathrm{~h}$ of exposure, the linoleate-enriched cells produced from 50 to $75 \%$ less $\mathrm{PGI}_{2}$ than the control cells. These differences between the linoleate-enriched and the control cells are similar to those observed when $\mathrm{PGI}_{2}$ production was stimulated by thrombin, but the reductions in the oleate-enriched cells are

TABLE VI

Prostacyclin Production by Cultured Human Endothelial Cells in Response to the Calcium Ionophore A23187*

\begin{tabular}{ccccc}
\hline & \multirow{2}{*}{$\begin{array}{c}\text { Time of } \\
\text { exposure } \\
\text { to fatty } \\
\text { acid }\end{array}$} & \multicolumn{3}{c}{ PGI $_{2}$ formed } \\
\cline { 3 - 5 } \cline { 4 - 5 } & & Control & Oleic & Linoleic \\
\hline & $15 \mathrm{~min}$ & 164 & 146 & 119 \\
1 & $1 \mathrm{~h}$ & 220 & 228 & 192 \\
2 & $3 \mathrm{~h}$ & 178 & 160 & 128 \\
3 & $72 \mathrm{~h}$ & 246 & 226 & 116 \\
4 & $72 \mathrm{~h}$ & 200 & NT $t$ & 35 \\
5 & & & &
\end{tabular}

* The procedure was the same as that described in Fig. 1, except that $10 \mu \mathrm{M} \mathrm{A23187}$ was employed instead of thrombin to elicit $\mathrm{PGI}_{2}$ release. The values at $15 \mathrm{~min}$ to $3 \mathrm{~h}$ are the averages of two separate cultures; those at $72 \mathrm{~h}$ are the means of three cultures. In experiments $1-3$, the cells were cultured for $72 \mathrm{~h}$ in regular growth medium and then exposed for the times indicated to either the control or a fatty acid supplemented medium. In experiments 4 and 5 , the cells were cultured with either the control or fatty acid supplemented medium directly for $72 \mathrm{~h}$. In all cases, the test medium was removed and the cells washed before exposure to the ionophore solution.

$\ddagger$ Oleic acid was not tested in this experiment. 
considerably less than those produced in response to thrombin.

Reversion of linoleate-enriched cells. The recovery of cells enriched with linoleic acid with respect to fatty acid composition and the capacity to release $\mathrm{PGI}_{2}$ was tested. Cell cultures were grown for $24 \mathrm{~h}$ in a medium supplemented with $150 \mu \mathrm{M}$ linoleic acid and then washed and transferred to an unsupplemented medium. During the subsequent $72 \mathrm{~h}$, cultures were taken for analysis of fatty acid composition and measurement of $\mathrm{PGI}_{2}$ release in response to thrombin. For clarity, compositional results are presented only for 18:2 and 20:4 in Fig. 2. When the medium was changed, the cell lipids were highly enriched in 18:2. During subsequent culture in the unsupplemented medium, the 18:2 content of the cell phospholipids and neutral lipids decreased progressively. There was no ap-

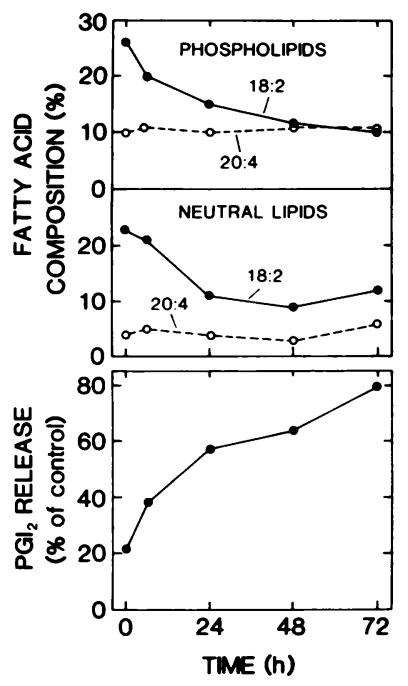

FIGURE 2 Prostacyclin release and fatty acid compositional changes during reversion of cells supplemented with linoleic acid. Cultured endothelial cells were exposed for an initial $24-\mathrm{h}$ period to medium supplemented with $150 \mu \mathrm{M}$ linoleic acid. This medium then was removed, and fresh medium containing no supplemental fatty acid was added. Three of the cultures were taken immediately for measurement of $\mathrm{PGI}_{2}$ release, and this set is shown as $0 \mathrm{~h}$. Additional sets of three cultures were assayed for $\mathrm{PGI}_{2}$ release at $6,24,48$, and $72 \mathrm{~h}$ after transfer to the unsupplemented medium. At each time, three control cultures treated in the same way except that they were exposed to an unsupplemented medium during the initial 24 -h period also were assayed for $\mathrm{PGI}_{2}$ release. The stimulus for $\mathrm{PGI}_{2}$ release was $0.5 \mathrm{U}$ of thrombin. Average values were calculated for the control and linoleate enriched cells at each time, and the $\mathrm{PGI}_{2}$ release of the linoleateenriched cells is shown as a percentage of the corresponding control cells. The fatty acid composition of a separate culture of cells that had been exposed to linoleic acid during the initial 24-h period was determined at the time of transfer to the unsupplemented medium. Additional cultures were assaye $\mathrm{d}$ for fatty acid composition at subsequent times during the reversion period. For clarity, only the percentages of linoleic (18:2) and arachidonic acid (20:4) are shown. preciable change, however, in the 20:4 content of these lipid fractions. The decreasing percentage of 18:2 was compensated for primarily by increases in 16:0, 18:0, and 18:1.

Fig. 2 also shows the $\mathrm{PGI}_{2}$ release at various times during the reversion period. Release is shown as a percentage of that observed in corresponding control cultures that were exposed to the unsupplemented medium during the initial 24-h period. At the start of the reversion period, only $22 \%$ as much $\mathrm{PGI}_{2}$ was released from the cells initially exposed to linoleic acid as compared with the control cells. As reversion progressed, $\mathrm{PGI}_{2}$ released from the cells enriched initially with linoleic acid increased, and after $72 \mathrm{~h}$ it reached $80 \%$ of the control value. These findings suggest that the lesser capacity of the cells exposed to linoleic acid to release $\mathrm{PGI}_{2}$ in response to thrombin is related to the increase in 18:2 content rather than to the decrease in 20:4 content.

\section{DISCUSSION}

These results indicate that the fatty acid composition of human endothelial cells can be modified in culture and that certain of these modifications affect the ability of the cells to produce $\mathrm{PGI}_{2}$ in response to external stimulation. Although some reduction in $\mathrm{PGI}_{2}$ release was obtained when the culture medium was supplemented with either oleic or linolenic acids, the most striking decrease occurred with linoleic acid. This decrease probably is not caused by a reduction in the content or inherent activity of the prostaglandin biosynthetic enzymes, for the linoleate-enriched cells produced almost as much $\mathrm{PGI}_{2}$ as the control cells when high concentrations of unbound arachidonic acid were available in the medium. A mechanism involving changes in membrane fluidity also appears to be unlikely, for the system should not have produced large quantities of $\mathrm{PGI}_{2}$ in response to $20 \mu \mathrm{M}$ arachidonic acid if the enzymes were embedded in a restrictive lipid environment. Furthermore, reductions in $\mathrm{PGI}_{2}$ release occurred at early time points when the overall unsaturation of the membrane lipids was changed only slightly. The mechanism also is unlikely to involve the thrombin receptor, for the effect occurred when the calcium ionophore was used to by-pass the thrombin activation process. These exclusions suggest that the mechanism involves a direct effect of the change in cellular linoleic and arachidonic acid content.

The most likely possibility is that a prostaglandin biosynthetic enzyme, probably cyclooxygenase, is inhibited by the increase in intracellular linoleic acid. In sheep vesicular gland and rat stomach extracts, prostaglandin synthesis is inhibited when linoleic acid is added (25). A similar inhibition occurs in microsomes prepared from human epidermis and platelets $(26,27)$. Although 
direct evidence is not available for endothelial cell preparations, our findings are consistent with a linoleic acid inhibition mechanism. The reversion experiment demonstrates that the recovery of $\mathrm{PGI}_{2}$-releasing capacity correlates with decreasing cellular linoleic acid content (Fig. 2). In addition, the arachidonic acid assay indicates that the decrease in $\mathrm{PGI}_{2}$ production can be overcome as the availability of substrate is increased (Table IV). This suggests that linoleic acid may be acting as a competitive inhibitor.

In such a mechanism, intracellular unesterified linoleic acid would be the actual inhibitor. Cells obtain unesterified fatty acid from either the surrounding medium or the hydrolysis of intracellular lipid esters (28). Because the endothelial cells were washed with albumin after culture, most of the unesterified fatty acid taken up from the medium probably was removed (29). Therefore, unesterified fatty acid contained in the cells at the time of the $\mathrm{PGI}_{2}$ assay must have been derived primarily from intracellular lipid esters. Rapid and continuous release of fatty acid from intracellular phospholipid pools has been demonstrated in mammalian cells (30). As a result of such turnover, the cell unesterified fatty acid pool would be expected to contain more linoleic acid when the intracellular phospholipids are enriched in linoleate, thereby having a higher inhibitor concentration. An alternative but related mechanism is that inhibitory concentrations of linoleic acid may be released from phospholipids when the cells are stimulated by either thrombin or the calcium ionophore. In normal human platelets, however, thrombin specifically releases arachidonate, and the linoleic content of the intracellular free fatty acid pool does not increase in response to stimulation (31). This selectivity argues against a specific release mechanism involving linoleic acid. Because it is not known whether the release in platelets would remain specific if they were enriched in linoleate, this possibility cannot be totally excluded.

Although our findings support an inhibitory role for linoleate, the associated decrease in the arachidonic acid content of the cell lipids also could be responsible for the lesser $\mathrm{PGI}_{2}$ release in response to external stimulation. The quantity of arachidonic acid in cell lipids has been shown to regulate prostaglandin production in mouse fibroblasts (32). Likewise, reductions in tissue arachidonate content caused by feeding diets low in essential fatty acids lead to a decrease in prostaglandin production (33). Infants who develop essential fatty acid deficiency during total parenteral nutrition also excrete less urinary prostaglandin metabolites (34). Furthermore, the phospholipid fractions that exhibit the largest decrease in arachidonate, the choline phosphoglycerides and the fraction containing the inositol phosphoglycerides, provide the arachidonic acid for prostaglandin synthesis in human platelets
$(31,35,36)$. Even if diglycerides actually are the direct source of the arachidonic acid, they appear to be derived in the platelet from inositol phosphoglycerides $(36,37)$. Although a mechanism involving a lesser availability of arachidonic acid in cellular lipids is consistent with many of our findings, it cannot explain the reduced $\mathrm{PGI}_{2}$ production when low concentrations of arachidonate are added to the assay (Table IV). Under these conditions, most of the $\mathrm{PGI}_{2}$ is derived from the added arachidonic acid, and the intracellular arachidonate content should not appreciably affect the amount of available substrate. Therefore, if the mechanism involves the reduced arachidonate content of the cellular phospholipids, one or more additional factors must be invoked to explain this finding as well as the results of the reversion studies.

Inasmuch as arachidonic acid is formed from linoleic acid, it is surprising that enrichment with linoleate causes a reduction in the arachidonate content of the cell phospholipids. This finding, however, is not peculiar to endothelial cells. Human skin fibroblasts contain $58 \%$ less arachidonate in phospholipids when they are enriched with linoleate in culture (22). Likewise, enrichment of mouse peritoneal macrophages with linoleate leads to a $55 \%$ reduction in arachidonate content (38). On the other hand, the arachidonate content increases in mouse astroblasts when they are enriched with linoleate (39), indicating that the effect is not generalized.

The finding that linoleate enrichment is associated with reduced $\mathrm{PGI}_{2}$ release is potentially important clinically. Linoleic acid is the predominant polyenoic fatty acid in many of the currently used diets that are high in polyunsaturated fat, such as those containing corn, safflower, or sunflower seed oil. When these diets are consumed for $1-2 \mathrm{wk}$, there is a large increase in the percentage of linoleic acid in the plasma lipoproteins (40-42). Moreover, the chylomicron triglycerides and the plasma free fatty acids become highly enriched with linoleic acid within 4-6 h after a single meal containing corn oil or safflower oil (43-46), and they remain enriched with linoleic acid for 35-47 h after such a meal (40). In the plasma free fatty acid fraction, linoleic acid accounts for $40-50 \%$ of the fatty acids after ingestion of safflower oil, whereas it accounts for only $15 \%$ of the plasma free fatty acids in the fasting state (46). By contrast, a decrease in the percentage as well as the total amount of arachidonate in the plasma free fatty acid fraction occurred when safflower oil was fed (46). Therefore, it appears that the plasma bathing the endothelium is highly enriched in linoleic acid but not in arachidonic acid when large quantities of the commonly available polyunsaturated fats are ingested. These results suggest that the endothelium may accumulate linoleic acid under these conditions and that this may reduce its capacity to release $\mathrm{PGI}_{2}$. Inasmuch 
as $\mathrm{PGI}_{2}$ inhibits platelet aggregation $(1,2)$, it is possible that the protective capacity of the endothelium against thrombosis may be reduced when increased quantities of polyunsaturated fats are consumed.

\section{ACKNOWLEDGMENT}

This work was supported by an Arteriosclerosis Specialized Center of Research grant from the National Heart, Lung, and Blood Institute, National Institutes of Health (HL 14230).

\section{REFERENCES}

1. Moncada, S., R. Gryglewski, S. Bunting, and J. R. Vane. 1976. An enzyme isolated from arteries transforms prostaglandin endoperoxides to an unstable substance that inhibits platelet aggregation. Nature (Lond.) 263: $663-665$.

2. Marcus, A. J. 1978. The role of lipids in platelet function: with particular reference to the arachidonic acid pathway. J. Lipid. Res. 19: 793-826.

3. Sun, F. F., J. P. Chapman, and J. C. McGuire. 1977. Metabolism of prostaglandin endoperoxide in animal tissues. Prostaglandins. 14: 1055-1074.

4. Pace-Asciak, C. R. 1977. Oxidative biotransformations of arachidonic acid. Prostaglandins. 13: 811-817.

5. Bunting, S., R. Gryglewski, S. Moncada, and J. R. Vane. 1976. Arterial walls generate from prostaglandin endoperoxides a substance (prostaglandin $\mathrm{X}$ ) which relaxes strips of mesenteric and coeliac arteries and inhibits platelet aggregation. Prostaglandins. 12: 897-913.

6. Moncada, S., A. G. Herman, E. A. Higgs, and J. R. Vane. 1977. Differential formation of prostaglandin (PGX or $\mathrm{PGI}_{2}$ ) by layers of the arterial wall. An explanation for the anti-thrombotic properties of vascular endothelium. Thromb. Res. 11: 323-344.

7. Weksler, B. B., A. J. Marcus, and E. A. Jaffe. 1977. Synthesis of prostaglandin $\mathrm{I}_{2}$ (prostacyclin) by cultured human and bovine endothelial cells. Proc. Natl. Acad. Sci. U.S.A. 74: 3922-3926.

8. Marcus, A. J., B. B. Weksler, and E. A. Jaffe. 1978. Enzymatic conversion of prostaglandin endoperoxide $\mathrm{H}_{2}$ and arachidonic acid to prostacyclin by cultured human endothelial cells. J. Biol. Chem. 253: 7138-7141.

9. Weksler, B. B., C. W. Ley, and E. A. Jaffe. 1978. Stimulation of endothelial cell prostacyclin production by thrombin, trypsin, and the ionophore A 23187. J. Clin. Invest. 62: 923-930.

10. Jaffe, E. A., and B. B. Weksler. 1979. Recovery of endothelial cell prostacyclin production after inhibition by low doses of aspirin. J. Clin. Invest. 63: 532-535.

11. Czervionke, R. L., J. B. Smith, G. L. Fry, J. C. Hoak, and D. L. Haycraft. 1979. Inhibition of prostacyclin by treatment of endothelium with aspirin. Correlation with platelet adherence. J. Clin. Invest. 63: 1089-1092.

12. Czervionke, R. L., J. B. Smith, J. C. Hoak, G. L. Fry, and D. L. Haycraft. 1979. Use of a radioimmunoassay to study thrombin-induced release of $\mathrm{PGI}_{2}$ from cultured endothelium. Thromb. Res. 14: 781-786.

13. Hoak, J. C., R. L. Czervionke, and L. J. Lewis. 1974. Uptake and utilization of free fatty acids (FFA) by human endothelial cells. Thromb. Res. 4: 879-883.

14. Nordøy, A., B. Svensson, and J. C. Hoak. 1979. The effects of albumin bound fatty acids on the platelet inhibitory function of human endothelial cells. Eur. J. Clin. Invest. 9: 5-10.

15. Dunbar, L. M., and J. M. Bailey. 1975. Enzyme dele- tions and essential fatty acid metabolism in cultured cells. J. Biol. Chem. 250: 1152-1153.

16. Aeberhard, E. E., L. Corbo, and J. H. Menkes. 1979. Polyenoic acid metabolism in cultured human skin fibroblasts. Lipids. 13: 758-767.

17. Czervionke, R. L., J. C. Hoak, and G. L. Fry. 1978. Effect of aspirin on thrombin-induced adherence of platelets to cultured cells from the blood vessel wall. J. Clin. Invest. 62: 847-856.

18. Jaffe, E. A., R. L. Nachman, C. G. Becker, and C. R. Minnick. 1973. Culture of human endothelial cells derived from umbilical cord veins. Identification of morphologic and immunologic criteria. J. Clin. Invest. 52: 2745-2756.

19. Lowry, R. R., and I. J. Tinsley. 1975. Rapid colorimetric determination of free fatty acids. J. Am. Oil Chem. Soc. 53: 470-472.

20. Smith, J. B., M. L. Ogletree, A. M., Lefer, and K. C. Nicolaou. 1978. Antibodies which antagonise the effects of prostacyclin. Nature (London) 274: 64-65.

21. Folch, J. M., M. Lees, and G. H. Sloane-Stanley. 1957. A simple method for the isolation and purification of total lipids from animal tissues. J. Biol. Chem. 226: 497-509.

22. Spector, A. A., R. E. Kiser, G. M. Denning, S-W. M. Koh, and L. E. DeBault. 1979. Modification of the fatty acid composition of cultured human fibroblasts. J. Lipid Res. 20: 536-547.

23. Morrison, W. R., and L. M. Smith. 1964. Preparation of fatty acid methyl esters and dimethylacetals from lipids with boron fluoride-methanol. J. Lipid Res. 5: 600-608.

24. Salmon, J. A., D. R. Smith, R. J. Flowers, S. Moncada, and J. R. Vane. 1978. Further studies on the enzymatic conversion of prostaglandin endoperoxide into prostacyclin by porcine aorta microsomes. Biochim. Biophys. Acta. 523: 250-262.

25. Pace-Asciak, C., and L. S. Wolfe. 1968. Inhibition of prostaglandin synthesis by oleic, linoleic and linolenic acids. Biochim. Biophys. Acta. 152: 784-787.

26. Ziboh, V. A. 1973. Biosynthesis of prostaglandin $E_{2}$ in human skin: subcellular localization and inhibition by unsaturated fatty acids and anti-inflammatory drugs. $J$. Lipid Res. 14: 377-384.

27. Gerrard, J. M., J. G. White, and W. Krivit. 1976. Labile aggregation stimulating substance, free fatty acids and platelet aggregation. J. Lab Clin. Med. 87: 73-82, 1976.

28. Spector, A. A. 1971. Metabolism of free fatty acids. Prog. Biochem. Pharmcol. 6: 130-176.

29. Spector, A. A. 1968. The transport and utilization of free fatty acid. Ann. N. Y. Acad. Sci. 149: 768-783.

30. Spector, A. A., and D. Steinberg. 1967. Turnover and utilization of esterified fatty acids in Ehrlich ascites tumor cells. J. Biol. Chem. 242: 3057-3062.

31. Bills, T. K., J. B. Smith, and M. J. Silver. 1977. Selective release of arachidonic acid from the phospholipids of human platelets in response to thrombin. J. Clin. Invest. 60: $1-6$.

32. Hong, S. L., G. Patton, and D. Deykin. 1979. Arachidonic acid level in cellular lipids determines the amount of prostaglandins synthesized during cells growth in tissue culture. Prostaglandins. 17: 53-59.

33. Mathias, M. M., and J. Dupont. 1979. The relationship of dietary fats to prostaglandin biosynthesis. Lipids. 14: 247-252.

34. Friedman, Z., S. Hannsjorg, J. Frolich, and J. Oates. 1979. Effects of dietary variation in linoleic acid content on the major urinary metabolites of the $E$ prostaglandins (PGE-M) in infants. 4th International Prostaglandin Conference 37. (Abstr.) 
35. Bills, T. K., J. B. Smith, and M. J. Silver. 1976. Metabolism of $\left[{ }^{14} \mathrm{C}\right]$ arachidonic acid by human platelets. Biochim. Biophys. Acta. 424: 303-314.

36. Rittenhouse-Simmons, S. 1979. Production of diglyceride from phosphatidylinositol in activated human platelets. J. Clin. Invest. 63: 580-587.

37. Bell, R. L., D. A. Kennerly, N. Stanford, and P. W. Majerus. 1979. Diglyceride lipase: a pathway for arachidonate release from human platelets. Proc. Natl. Acad. Sci. U.S.A. 76: 3238-3241.

38. Schroit, A. J., and R. Gallily. 1979. Macrophage fatty acid composition and phagocytosis: effect of unsaturation on cellular phagocytic activity. Immunology. 36: 199-205.

39. Robert, J. G., G. Rebel, and P. Mandel. 1977. Essential fatty acid metabolism in cultured astroblasts. Biochemie (Paris). 59: 417-423.

40. Kayden, H. J., A. Karmen, and A. Dumont. 1963. Alteration in the fatty acid composition of human lymph and serum lipoproteins by single feedings. J. Clin. Invest. 42: $1373-1381$.

41. Spritz, N., and M. A. Mishkel. 1969. Effects of dietary fats on plasma lipids and lipoproteins: an hypothesis for the lipid lowering effect of unsaturated fatty acids. J. Clin. Invest. 48: 78-86.

42. Shephard, J., C. J. Packard, J. R. Patsch, A. M. Gotto, Jr., and O. D. Taunton. 1978. Effects of dietary polyunsaturated and saturated fat on the properties of high density lipoproteins and the metabolism of apolipoprotein A-I. J. Clin. Invest. 61: 1582-1592.

43. Bragdon, J. H., and A. Karmen. 1960. The fatty acid composition of chylomicrons of chyle and serum following the ingestion of different oils. J. Lipid Res. 1: 167-170.

44. Bragdon, J. H., and A. Karmen. 1961. Effect of ingested fat on fatty acid composition of serum lipoproteins. J. Lipid Res. 2: 400-402.

45. Nichols, A. V., C. S. Rehnborg, F. T. Lindgren, and R. D. Wills. 1962. Effect of oil ingestion on lipoprotein fatty acids in man. J. Lipid Res. 3: 320-326.

46. Heimberg, M., G. D. Dunn, and H. G. Wilcox. 1974. The derivation of plasma free fatty acids from dietary neutral fat in man. J. Lab. Clin. Med. 83: 393-402. 